\title{
Effect of Student Teamss Achievement Division (STAD) on Mathematical Learning Results in SDLB Surabaya
}

\author{
Lia Agustini \\ Department of Spesial Education, Faculty of Education Science, University Negeri Surabaya, Surabaya, East Jawa, Indonesia \\ liaagustini1423@gmail.com \\ ${ }^{*}$ Corresponding Author
}

How to Cite: Agustini, L. (2019). Effect Of Student Teamss Achievement Division (STAD) On Mathematical Learnig Result In SDLB In Surabaya. International Journal for Educational and Vocational Studies, 1 (6), 554-559

\section{ARTICLE HISTORY}

Received:3 July 2019

Revised: 23 August 2019

Accepted: 10 September 2019

\section{KEYWORDS}

Student Teams Achievement Divisions; Mathematics Learning Outcome;

\begin{abstract}
Researcher's applied Student Teams Achievement Division (STAD) with the goals students' learning skills in elementary schools, Majesty I Surabaya. The approach used in this research is quantitative. The research was pre experiment. The design used the one group pre test and post test. The method was tested, to collect data from mathematic learning results before and after giving intervention. The application of intervention was conducted 10 times meeting with the time allocation 60 minutes each meeting. The data analysis used is a non parametric statistic, a sign test. The analysis result was used to sign a test that could be concluded that there was a significant influence using Student Team Achievement Division (STAD) toward student learning in SDLB-B Noble work I Surabaya with ZH value $=2,05>\mathrm{Z}$ table $5 \% 1,96$.
\end{abstract}

This is an open access article under the CC-BY-SA license.

\section{INTRODUCTION}

Students with special needs who have difficulty learning mathematics generally are categorized as students with special learning difficulties. They have talent in the academic field. Although students who are categorized as Children with Special Needs encounter difficulties when working on math problems, but mathematics subjects are still taught in school. This is because understanding of mathematical problems can help students to be able to live independently in their environment in daily life (Delphie, 2009: 27). Deaf children are one of the Children with Special Needs who have intellectual, emotional, social, and behavioral obstacles. They need special education and services so that they are knowledgeable and able to socialize in the community. The learning model needs to be understood by the teacher in order to be able to implement learning effectively in improving learning outcomes. The limitations of children who are deaf in receiving auditive information cause cognitive development to be hampered. Obstacles experienced by deaf children result in a decrease in academic achievement which results in learning outcomes tend to be low. As in the field of mathematics studies that require students to have the ability to think abstractly. This is an obstacle for deaf children in understanding mathematical concepts (Somad and Hernawati, 1996: 27). In abstract - mathematics learning, students need tools in the form of media, and teaching aids that can clarify what will be conveyed by the teacher so that it is more quickly understood and understood by students.

In every opportunity, mathematics learning should begin with the introduction of problems that are appropriate to the situation (contextual problem). The results of Suryadi's study (in Isjoni, 2011: 12) state that one of the effective learning models to improve mathematics learning abilities is cooperative learning. Student Teams Achievement Division (STAD) is one of the cooperative learning modelsthe simplest (Slavin, 2005: 143). In this case it will be able to help students, especially deaf students to improve the positive attitude of students in mathematics. Students individually build confidence in their ability to solve mathematical problems. The main idea of STAD is to motivate students to be able to support and help one another in mastering the abilities taught by the teacher.

Learning outcomes are the result of an interaction between learning and teaching (Dimyati and Mudjiono 2002: 3). The educational goals to be achieved can be categorized into three fields, namely the cognitive field (intellectual mastery), the affective field (related to attitudes and values) and the psychomotor field (ability/ 
skill to act/behave). All three do not stand alone, but are an inseparable whole, even forming a hierarchical relationship. That is why the three aspects must be viewed as student learning outcomes from the teaching process (Sudjana 2004: 49). Learning outcomes achieved by students are influenced by two main factors, namely factors from within students and factors from outside of students or environmental factors. Besides the ability factor that students have, there are also other factors such as learning motivation, interest and attention, attitudes and learning habits, perseverance, socio-economic, physical factors, and psychological. Learning outcomes can also be achieved depending on the environment. This means that there are factors outside of him that can determine or influence the learning outcomes achieved. One of the most dominant learning environments affecting school learning outcomes is the quality of teaching. The definition of teaching quality is the high or low or the effectiveness of the teaching and learning process in achieving the teaching goals.

Learning outcomes in essence are implicit in the purpose of teaching. Therefore student learning outcomes in schools are influenced by students' abilities and the quality of teaching. Both of these factors, student ability and quality socio-economic, physical, and psychological factors. Learning outcomes can also be achieved depending on the environment. This means that there are factors outside of him that can determine or influence the learning outcomes achieved.

One of the most dominant learning environments affecting school learning outcomes is the quality of teaching. The definition of teaching quality is the high or low or the effectiveness of the teaching and learning process in achieving the teaching goals. Learning outcomes in essence are implicit in the purpose of teaching. With the result that student learning outcomes in schools are influenced by students' abilities and the quality of teaching. Both of these factors, student ability and quality teaching has a relationship directly proportional to student learning outcomes. That is, the higher the student's ability and the quality of teaching, the higher the student learning outcomes (Sudjana 2004: 40).

Results of the werw conducted by Sam, showed result that the device learning realistic setting of STAD in terms of aspect can be declared valid and feasible to use in teaching mathematics. Specific findings that are considered important in this study are students who are very interested, enthusiastic and interested follow math eatical learning

Cooperative Learning comes from the word cooperative which means doing things together by helping one another as one group or one team (Isjoni, 2011: 15). The characteristics of cooperative learning are as follows: (a) Each member has a role, (b) There ais a direct interaction between students, (c) Each group member is responsible for learning and group friends, (d) The teacher's role helps students to develop group interpersonal skills, (e)Teachers only interact with groups when needed.

The main objective in implementing Cooperative Learning teaching and learning models is so that students can learn in groups with their friends by respecting opinions and giving others the opportunity to express their ideas by expressing their opinions in groups. By implementing Cooperative Learning learning models, students can achieve success in learning, while also training students to have skills, both thinking skills (Thingking skills) and social skills (Social skills), such as the skill to express opinions, accept suggestions and input from others, cooperate, feel solidarity, and reduce the emergence of deviant behavior in class life (Isjoni, 2011: 21:23). There are various theories that we learn in Cooperative Learning. Three of them are as follows:

\section{a. Ausubel Theory}

According to Ausubel in Isjoni (2011: 35) the learning material learned must be "meaningful" (Meaning full ). Meaningful learning is a process of linking new information to relevant concepts contained in one's cognitive structure. Cognitive structures are facts, concepts, and generalizations that students have learned and remembered. Meaningful learning occurs when students try to connect new phenomena to the structure of their knowledge. The emotional intellectual factors of students will be involved in learning activities. Thus, Cooperative Learning will be able to repel boredom and boredom. According to Ausubel in Isjoni (2011: 37), suitable problem solving is more beneficial for students and is an efficient strategy in learning.

\section{b. Piaget's Terror}

In relation to the levels of development proposed by Piaget, learning refers to learning activities that must involve the participation of students. So that according to this theory, his knowledge is not merely moved verbally but must be constructed and reconstructed by students. As the realization of this theory, students must be active in learning activities. Cooperative Learning is a model of active and participatory learning.

\section{c. Vygotsky's theory}

Vygotsky argues that learning is a development of understanding. He states that there are two spontaneous and scientific meanings. What students learn at school influences the development of concepts obtained in everyday life and vice versa. Vygotsky's contribution and theory is an emphasis on socio-cultural talent in learning. According to him learning occurs when children work in the zone of proximal development. In Vygotsky's theory, there is a direct relationship between the cognitive domain and socio-culture. The quality of thinking of students is built in the classroom, while social activities are developed in the form of cooperation between students and other students who are better able under the 
guidance of adults in this case the teacher.

Bannet in Isjoni (2011: 41) states that there are five basic elements that can distinguish Cooperative Learning with group work, namely:

a. Positive Interdependence

b. Interaction Face to Face

c. There is a personal responsibility regarding subject matter in group members

d. Requires flexibility

There are many types of cooperative learning that have been developed and studied, including Student Teams Achievement Division (STAD) or Team Achievement Student Groups, Teams Games Tournament (TGT) or team game matches, Teams Assisted Individualization (TAI) or individually assisted by Teams, Coopratife Integerated Reading and Compotision (CIRC) or integrated cooperative teaching reading and writing, jigsaw and others.

Among the several types described above STAD are the simplest and are suitable for mathematics learning. In the learning process, learning the STAD type through five stages which include: 1) Class presentation, 2) Team, 3) Quiz 4) Individual progress score, and 5) Team Recognition.

\section{1) Class presentation}

The material in STAD was first introduced in presentations in class. This is direct teaching as often discussions are conducted by teacher-led lessons, but can also include audio-visual presentations. The difference is that class presentations with ordinary teaching are just that the presentation must really focus on the STAD unit. In this way, students will realize that they must really pay full attention during class presentations, because it will greatly help them work on the quizzes, and their quiz scores determine their team's score.

\section{2) Team}

Teams consist of four or five representing all parts of the class in terms of academic performance, gender, race and ethnicity. The main function of the team is to ensure that all team members really learn, and more specifically, is to prepare its members to be able to do the quiz well. After the teacher delivers the material, the team gathers to study the activity sheet or other material. Most often, learning involves discuss common problems, compare answers, and correct any misconceptions if a team member makes a mistake. The team is the most important feature in STAD. At each point, the emphasis is on making team members do their best for the team, and the team must do their best to help each member. This team provides group support for important academic performance in learning, and that is to provide mutual attention and respect that are important for the resulting outcomes such as inter-group relations, sense of self-esteem, acceptance of mainstream students.

\section{3) Quiz}

After about one or two periods after the teacher gives a presentation and about one or two periods of team practice, students will work on individual quizzes. Students are not allowed to help each other in doing quizzes. So that each student is individually responsible for understanding the material.

4) Individual progress score

The idea behind the score of individual progress is to give each student the performance goals that can be achieved if they work harder and provide better performance than before. Each student can contribute maximum points to his team in this score, but no student can do it without giving their best effort. Each student is given an initial score which is obtained from the average student performance before working on the same quiz. Students will then collect points for their team based on the level of increase in their quiz score compared to their initial score.

\section{5) Team Recognition}

The team will get a certificate or other form of appreciation if their average score reaches certain criteria. Student team scores can also be used to determine twenty percent of their rank.

The aim of the initial score and the progress points is to allow all students to give maximum points to their group, regardless of their previous level of performance. Team score. To calculate team scores is to record each progress point of all team members on the team summary sheet and divide all team members on the team summary sheet and for the total number of progress points of all team members with the number of team members present.

Table 1. Team Recognition

\begin{tabular}{cc} 
& Award level \\
\hline Criteria (team average) & Appreciation \\
\hline 15 & Good Team \\
\hline 16 & Team Is Very Good \\
\hline 17 & Super Team \\
\hline
\end{tabular}

Source of Slavin (2005: 160)

Deafness is someone who is experiencing a lack or loss of hearing ability either partially or completely caused by the malfunctioning of part or all of the hearing instruments, so that he cannot use his hearing instruments in everyday life which has an impact on his life in a complex way. The impact on his life in a complex manner means that due to carnage the development of the child becomes hampered, thus inhibiting overall personality development, such as intelligence, emotional, and social development. Limitations in getting information, resulting in less developed abstraction power. Ketunarunguan has implications for the development of intelligence. Other opinions about the intelligence of deaf child. 


\section{METHODS}

In the study the authors used the type of research pre experiment with design study of quantitative pre-testing. The research in using the design study of quantitative pre experiment with the design "the one-group pretest-post test design" that is an exsperiment that was conducted on a logroup without using control comparison groups. The samples were used in the study is not to be random. The located in SDLB-B karya Muia 1 Surabaya which located in Jl Jend. A Yani 6-8, Wonokromo Surabaya with the subject as follows :

Table 2. Subject of Research

\begin{tabular}{|c|c|c|c|}
\hline \multirow[b]{2}{*}{ No } & \multirow[b]{2}{*}{ Name Students } & \multicolumn{2}{|c|}{ Value } \\
\hline & & $\begin{array}{l}\text { Pre-test } \\
(\mathrm{X})\end{array}$ & $\begin{array}{c}\text { Post-test } \\
\text { (Y) }\end{array}$ \\
\hline 1 & $\mathrm{BA}$ & 40 & 70 \\
\hline 2 & $\mathrm{Al}$ & 50 & 100 \\
\hline 3 & YOU & 50 & 80 \\
\hline 4 & $\mathrm{AF}$ & 40 & 70 \\
\hline 5 & $\mathrm{RI}$ & 50 & 100 \\
\hline 6 & RO & 40 & 90 \\
\hline & verage & 45 & 85 \\
\hline
\end{tabular}

The technique of collecting data in research uses the test method. Test are used by research this is a pre-test and post-test. The tes is to find out the mathematics learning outcomes before and after the intervention is given. Data analysis techniques used to analyze data in this study is analysis of non-parametric statistical data with quantitative data and the number of research samples is small, namely $\mathrm{n}=6$. Then thr formula that is used is "Test Signs".

The test was carried out 2 times before and after the Student Teams Achievement Division (STAD) was applied to deaf students in class III SDLB-B Karya Mulia I Surabaya and 10 meetings to give treatment to the problems to be studied. Each meeting lasts $2 \times 30$ minutes which is done 3 times a week. The location in this research is located in SDLB-B Karya Mulia I Surabaya which is located on Jl Jend A Yani 6-8, Wonokromo Surabaya. Research Subjects of Class I Students at SDLB B Karya Mulia I Surabaya.

Free variable $(\mathrm{X})$ is a variable that affects or becomes the cause of the change or the emergence of the dependent variable. The independent variable in this study was Student Teams Achievement Division (STAD). Dependent variable (Y) is a variable that is influenced or becomes a result, because of the existence of independent variables. The dependent variable in this study is the learning outcomes of mathematics.

The data analysis technique used in this study is the test method namely pre test and test post. The data analysis technique used to analyze the data in this study is the analysis of non-parametric statistical data with quantitative data and the number of research samples is small, namely $\mathrm{n}=6$. Then the formula used is "Test Sign" (Sign test) : $\mathrm{Zh}=\mathrm{x}-\mu$

\section{RESULTS AND DISCUSSION}

The results of the study show that Student Teams Achievement Divisions (STAD) have a significant inf luence that can improve mathematics learning outcomes. This can be seen from the results of pre-tests and tests. This tabel Recapitulation of pre-test \& post-test results before and after using cooperative learning type Student Teams Achievement Division (STAD). Work table changes in pre-test grades and class III student test posts SDLB-B Karya Mulia I Surabaya.

Table 3. Results of Pre-test-and Post-test

\begin{tabular}{|c|c|c|c|c|}
\hline \multirow[b]{2}{*}{ No } & \multirow{2}{*}{$\begin{array}{c}\text { Name } \\
\text { Students }\end{array}$} & \multicolumn{2}{|c|}{ Value } & \multirow{2}{*}{$\begin{array}{c}\text { Change } \\
\text { Sign } \\
(\mathrm{X} 2-\mathrm{X} 2)\end{array}$} \\
\hline & & $\begin{array}{c}\text { Pre-test } \\
(\mathrm{X})\end{array}$ & $\begin{array}{c}\text { Post-test } \\
(\mathrm{Y})\end{array}$ & \\
\hline 1 & $\mathrm{BA}$ & 40 & 70 & + \\
\hline 2 & $\mathrm{Al}$ & 50 & 100 & + \\
\hline 3 & YOU & 50 & 80 & + \\
\hline 4 & $\mathrm{AF}$ & 40 & 70 & + \\
\hline 5 & $\mathrm{RI}$ & 50 & 100 & + \\
\hline 6 & RO & 40 & 90 & + \\
\hline \multicolumn{2}{|c|}{ Average } & 45 & 85 & $X=6$ \\
\hline
\end{tabular}

The following is presented using the "test sign" ( sign test ) Zh. It is known : $\mathrm{n}=6$ and $\mathrm{p}=0.5$. Then:

$\mathrm{X}=$ number of marks plus $(+)-\mathrm{p}=60.5$

$$
=5.5
$$

a) Mean

$$
\text { Mean } \begin{aligned}
(\mu) & =\mathrm{n} \cdot \mathrm{p} \\
& =6.0 .5 \\
& =3
\end{aligned}
$$

b) Standard devision

$$
=\sqrt{ } \mathrm{n} \cdot \mathrm{p} \cdot \mathrm{q}
$$

$=\sqrt{ } 6 \cdot 0.5 \cdot 0,5$

$=\sqrt{ } 1.5$

$=1.22$

c) Statistical tests

$$
\begin{aligned}
\mathrm{Zh}=\mathrm{x}-\mu & =5.5-3 \\
= & 5.5-3=1.22 \\
& =2,049 \mathrm{Zh}=2,05
\end{aligned}
$$

d) Critical value

Critical value if $\alpha=5 \%=0.05$ (testing is done with two sides), then critical value

$= \pm \mathrm{Z}^{1 / 2} \mathrm{\alpha}= \pm 1.96$. H0 is accepted if $-1.96 \leq \mathrm{Zh} \leq+1.96$. H0 is rejected if $\mathrm{Zh}>+1.96$ or $\mathrm{Zh}<-1.96$

\section{e) Results of data processing}

A fact that the $\mathrm{Zh}$ value obtained in a statistical count is 2 , 05 greater than the critical value $\alpha=5 \%$ which is 1.96 so the null hypothesis is rejected and the working hypothesis is accepted. This proves that there is a significant influence in the use of Cooperative Learning Student Teams Achievement Divisions (STAD) type on mathematics learning outcomes in class III deaf students at SDLB-B Karya Mulia I Surabaya.

From the results of the two-sided tests that have been analyzed, it shows that the value of $\mathrm{Z}$, which is obtained in 
a count of 2.05 is greater than the critical value of $\mathrm{Z} 5 \%$, which is 1.96 so that the null hypothesis is rejected and the working hypothesis is accepted.

So that there is a significant increase in the learning outcomes of mathematics using the Student Teams Achievement Divisions (STAD) method on class III students at SDLB-B Karya Mulia I Surabaya. This seems to be a better change from the results of the pre-tests and the tests that have been carried out. Hearing loss makes the development of deaf children intelligence less developed. This is in accordance with the opinion of Soemantri (2006: 22) which states that cognitive development of deaf children is strongly influenced by language development, so that obstacles in language will hinder the intelligence aspects of deaf children. For Children with Special Needs especially for the Deaf, mathematics is an abstract subject. In every opportunity, mathematics learning should begin with the introduction of problems that are appropriate to the situation ( contextual problem ).

As stated by Syaiful Bahri (2010: 74) that the use of appropriate methods can support teaching and learning activities, so that it can be used as an effective tool to achieve teaching goalsThrough activities in providing interventions using cooperative learning models students can exchange ideas with other students, so that students who do not understand the material will understand better. Besides that in cooperative learning can also improve students' social abilities. As stated by Isjoni (2011: 21) that the main purpose in implementing cooperative learning teaching and learning models is so that students can learn in groups with friends by respecting opinions and giving other people the opportunity to express their ideas by expressing their opinions in groups.

Given that deaf children experience problems in language that affect their communication skills, so this has an impact on the ability of social interaction. By applying the cooperative learning model the type of Student Teams Achievement Division (STAD) can provide mutual experience interact and work together between group members in solving a problem from what is learned. This is in line with Vygotsky's theory which proposes a theory known as Zone of Proximal Development(ZPD) which is a socio-cultural dimension that is important as a psychological dimension.

At the beginning of the meeting, the atmosphere of the discussion still did not show the true meaning of Cooperative Learningthat is doing something together by helping one another as one group or one team (Isjoni, 2011: 15). Because there are some students who are ambitious to answer all questions. Even though the teacher had explained to the students that the importance of cooperation was established because it would affect their own team's score. Team score is the average value of the student's quiz development value per individual. After entering the activity of recognizing the team's score, then the students are well aware if the individual's value can influence the team's certificate that will be carried by the team, and it cannot be separated from teamwork and helping each other in working on the problem. This is similar to that expressed by Isjoni (2011: 21: 23), namely: By implementing Cooperative Learning learning models, students make it possible to achieve success in learning, besides it also trains students to have skills, both thinking skills (Thingking skills) and social skills (Social skills), such as the skill to express opinions, accept suggestions and input from others, cooperate, feel solidarity, and reduce the emergence of deviant behavior in class life. At the second meeting to the meeting the five researchers found it difficult to give understanding to students in the division of the discussion team, because the researchers wanted to unite the pattern of teamwork by means of heterogeneity, which brings together students whose achievements are in the "good", "moderate" and "not good" positions on individual quiz points at the previous meeting. Students who feel threatened the value of their team will be bad, they will protest if they are united with a child who is "not good". Deaf characteristics are what inhibit the development of children's personality toward maturity (Somad and Hernawati, 1995: 37-39).

When the researchers encountered this, the thing that is done is giving an explanation to students so that other students will accept the students "not good". Even researchers also provide assertiveness that individual values will influence the value of the team. Different things are shown in the sixth to eleventh or last meeting discussion, the competition that occurs in students becomes healthy competition, where each student competes to work hand in hand and help to help in helping his work to digest a material. This is the reason Vygotsky implies his learning theory which requires the existence of cooperative settings in learning, which read "this is the initial process for the child to know about himself and then in the future he will be able to evaluate himself, analyze the weaknesses and strengths they have "This is inversely proportional to the atmosphere that happened before. Seeing the conditions above, the atmosphere of learning will be very pleasant and not boring. This is in line with vygotsky's theory that the Zone of Proximal Development (ZPD) is the term Vygotsky for tasks that are too difficult for children to master themselves, but which can be mastered with guidance and assistance from adults or children who more skilled. Lower ZPD limits are the level of problem solving achieved by a child who works independently. And a higher limit is the level of additional responsibility that can be received by the child with the help of a capable instructor.

\section{CONCLUSION}

Based on data processing using data analysis techniques that have been described in the previous chapter, the results of mathematics learning for third grade students of SDLB-B Mulia Mulia I Surabaya using Student Teams Achievement Divisin (STAD) method have shown an increase. This is shown in the average column. In the application of the Student Teams Achievement Division in 
Class III SDLB-B Karya Mulia I Surabaya can provide a new and fresh atmosphere rather than learning as usual. Students become more active in the classroom and are more motivated to get better grades.

With the existence of such research results and supported by available data, therefore it is suggested to:

1. Teacher

From the results of significant data research and processing Student Teams Achievement Division (STAD) can be used as an alternative reference and selection method in improving learning outcomes in subjects other than mathematics that have the same type of teaching material characteristics.

\section{Advanced researchers}

For further researchers if they will examine the same research, the author recommends that:

a. Understanding the condition of the study sample that will be given an intervention

b. Understand the steps in the Student Teams Achievement Division (STAD)

c. Provide a variety of certificates so students can be motivated to study well.

\section{REFERENCES}

Delphie, Bandi. (2009). Mathematics for Children wi Special Needs. Sleman: PT Intan Klaten.

Dimyati and Mudjiyono. 2006. Learning and Learning. Jakarta: Rieneka Cipta.

Hariwijaya. (2009). Increasing mathematical intelligence. Yogyakarta: Tugupublisher.

Isjoni. (2011). Cooperative Learning. Bandung: Alfabeta

Somad, Permanarian and Tati Hernawati. 1996. Orthopedicagogics of

Deaf Children. Bandung: Department of Education and Culture.

Sudjana, N. (2004). Basics of the Teaching and Learning Process. Bandung: Sinar Baru ALGen Sindo

Slavin, Robert E. (2005). Cooperative Learning theory, research, and practice. Bandung: Nusa Media Publishers.

Arikunto, Suharsimi, (2010). Research Procedure A Practice Approach . Jakarta: Rineka Cipta.

BNSP, (2006). Standarr Competence and Competency Basic SDLB B. Jakarta: Agency Standards National Pendidkan

Djamarah and Aswan. (2010). Teaching Learning Strategis. Jakarta: PT Rineka Cipta

Djamarah, Syaiful Bahri. (2010). Teachers and children of students in interaction educative. Jakarta: Rineka Cipta

Hamzah. (2011). Learning Model. Jakarta: PT Bumi Aksara

Hasibuan, et al. (2008). The process of learning to teach . Bandung: PT. Teenager Rosdakarya.
Ibrahim, M.kk. (2000). Cooperative Learning . Surabaya UNESA University Press.

Runtukahu, Tombokan. (1996). Teaching Mathematics for Children with Learning Difficulties. Surabaya: Ministry of Education and Culture.

Sgl, Smsubr. (1996). Statistik Non Parametrik Edisi 2. Yogyakarta: BPFE.

Sugioyo. (2010). Methodology Penelitian Kuantitatif Kualitatif dan R \& D. Bandung: Alphabet

Suherman, Erman. (2001). Contemporary Mathematical Learning Strategies in Bandung: JICA

Suprijono, Agus. (2012). Cooperative Learning theory \& application of Paikem. Yogyakarta: Learning Library

Drafting team. (2006). Guide to writing and evaluating thesis at Surabaya State University. Surabaya: Unesa University Press

Trianto. (2011). Innovative learning models are constructivist oriented. Jakarta: Library Achievement. 